\title{
Long Term Immigrants as Teachers of New Immigrant Students
}

\author{
Adi Binhas \\ Ph.D, Mofet Institute (Tel-Aviv, Israel), \\ Beit Berl Academic College (Kfar Saba, Israel) \\ E-mail: adibinhas@gmail.com
}

This article deals with veteran immigrant teachers who integrated successfully into Israel's educational system and have been teaching immigrant students over the past few years. Their encounter with present (2018) new immigrants raises the following research question: How are patterns of integration into society reflected in the conceptions of veteran immigrant teachers in their work with immigrant students? The theoretical literature on which this study is based includes Berry's transnationalism model and the concept of hybrid identity. The results displayed affinity between the teachers' own migration stories and their educational conceptions regarding immigrant students. Patterns included both assimilation and integration. The conclusions declare that it is indeed appropriate to process the experiences and stories of veteran immigrant teachers because they transmit their conceptions to immigrant students and can serve as bridge builders within the educational system as former immigrants themselves.

Keywords: Transnationalism, hybrid identity, immigrant teachers, narrative paradigm, melting pot, multiculturalism

Received:May 29, 2019; accepted: September 3, 2019

Future Human Image, Volume 12, 2019: 5-21.

https://doi.org/10.29202/fhi/12/1

\section{Introduction}

In an era of globalization and migration, more and more people are moving from place to place around the world. Theories of migration present the various stages involved and describe the integration of immigrants into the host society [Berry, 1992].

Today, global migration is not only a physical change of residence, but also a measure affected by political, economic, cultural and family factors. Transnational theory expresses the various characteristics and components of identity that people take from place to place and how they cope with it. It effectively enables people to preserve their previous culture

(C) Binhas, Adi, 2019

Acknowledgments: Thanks and appreciation to Dr. Gabriela Spector-Marzel for the professional support in the process of preparation the article. Thank you for your creative ideas that help me to improve the article. 
while adopting a new one, to be both, as it were, by maintaining a hybrid culture. Literature on migration in the modern era refers to this phenomenon as well [Glick et al., 2004].

The educational system and teachers are major players in the process of integration into a new society. Teachers who are themselves former immigrants can exert a more significant influence as role models for immigrant students, especially because they understand the process of migration and all its implications from personal experience. Research on migration aspires towards having the teachers' room reflect the changing makeup of the population of teachers and students. Nevertheless, it lacks attention to the encounter between the former immigrant teacher and the immigrant student and the effects of this encounter on education itself, on the conceptions and actions of the teachers that originate in the experience and insights they accumulated over the years.

This study analyzes teachers of immigrant students who are themselves veteran immigrants from the Former Soviet Union (FSU), applying narrative analysis to identify the significance they ascribe to their own stories of immigration. It seeks to acquire information about the actual conceptions and actions of veteran immigrant teachers (VITs) when working with their immigrant students. The article was written according to the findings of interviews with VITs who came to Israel over 20 years ago - a feature that was brought up during interviews (none of the participating teachers were hired specifically as "immigrant teachers" by their respective schools). Work with immigrant students apparently reawakened their own immigrant experiences, leading them to think and act according to the significance they attach to them. Examination of the literature indicated that there are virtually no studies of VITs and the influence of their immigration on their conceptions and behavior. Hence our research question is: How are patterns of integration into society reflected in the conceptions of veteran immigrant teachers in their work with immigrant students?

Accordingly, the study uses Berry's model to learn about patterns of integration among teachers over the years. The research population consists of ten teachers, all of them women from the FSU, who moved to Israel during the 1990s at various ages ranging from childhood to their twenties. It is interesting to note the influence of immigrant students on the teachers, who essentially encounter their own immigration experiences through these students and find their unique identities more pronounced in the teachers' room and the entire school as speakers of their native languages and as mediators between immigrants and the school.

\section{Theoretical Background: Immigration, Transnationalism and Hybrid Identity}

Berry proposed a variety of options for describing integration of immigrants into host societies: Assimilation - those who do not want to preserve their original cultural identity but prefer adopting another; separation - individuals or groups who consider it important to maintain their original culture and seek to avoid interaction with and influence of others; integration - an individual or group interested in keeping the original culture but also interacting with members of other groups, wherein the original culture is preserved to a certain extent, along with a desire to be a partner in a broader social system that includes intentional interaction with the receiving community and marginalization - little interest in maintaining one's original culture, wherein whatever cultural preservation does exist is not ideologically motivated but random in nature and is barely concerned with relations with others from the receiving society because of physical/geographical, cultural, religious or 
other distance, engendering some movement towards the margins by the individual or group [Berry, 1992].

Along this continuum, there are also options for combinations, originating in the idea that migration does not obliterate the previous identity but enables it to be maintained in parallel with another, as transnational theory claims. This theory developed as part of the study of migrants and migration during the post-colonialist era and considers migration not only a process of people moving from country to country but one in which political, economic, cultural and family factors are involved as well. The host countries, in turn must make accommodations for the various identities [Wald, 2008], while the transnationalist conception creates a new angle of vision on migration, integration and identity [Gold, 2002]. Technological developments and globalization facilitate transnationalism and preservation of a contact network with the community of origin - a measure perceived as wholly legitimate in a multicultural era [Dinnerstein et al., 1990; Pries, 1999]. Migrants in our own time keep up contact with their previous identities at varying degrees of intensity. Some maintain powerful transnational ties, while others carry on less intense contact with their former or current identities [Faist, 2000]. The identity and intensity of activity can change, as can the context (e.g., economic, social, cultural or religious). These changes led to the conclusion that one should explore the characteristics of migrants in a broader and more complex, multidimensional and multilayered manner [Levitt et al., 2003]. Even the immigrants themselves are not always motivated to maintain contact with the original culture [Waldinger, 2017]. This study also attempts to cope with the effects of parallel identities and to increase our understanding of the patterns of relations among the various identities and the extent to which they can coexist. Hybridism describes the encounter between two cultural identities - a phenomenon that is becoming more and more widespread in the global era of transnationalism. Literature on hybrid identity, like that referring to transnationalism, relates to a multicultural phenomenon from a new point of view. Theoreticians identified with such links have described various combinations among identities [Bhabha, 1994; Hall, 1992; Young, 1995].

In the cultural context, Bhabha presents the possibility of an identity in which different cultural characteristics can exist in parallel [Bhabha, 1994]. For example, he claims that colonial authorities and their subjects exert a reciprocal influence on shaping one another's identity: The colonial regime absorbs values and cultural features from the society it rules and also exposes the locals to another culture, enabling redefinition of their self-identification. In other words, one may be both, with reciprocal influences between cultures.

Attention to hybridity in the Israeli context appeared in studies that concerned the variety of identities and the ability of groups to maintain their original characteristics in Israel as well [Kimmerling, 1998; Shenhav, 2006]. In this study, transnational approaches and hybrid identities are connected to Berry's approach, which presents the model of integration between identities, the previous and the new, as a result of combination, without elimination or obliteration.

\section{Teaching in an Era of Transnationalism and Hybrid Identities among Teachers}

The immigrant teachers described in this study moved to Israel over 20 years ago. Even though they are Israelis and not defined as immigrants, they are still familiar with both societies and cultures. Hence the study will relate to their hybrid identity. Studies concerned 
with the development of teachers' professional identity claim that it is based and dependent on four factors: Social, cultural, historical and political contacts; relationships with others; dynamic nature and attempt at coherence [Beijaard et al., 2000; Rodgers \& Scott, 2009]. As part of the hybrid identity of teachers, we should also consider the context of language and bilingualism in its broader sense, both at the learning and emotional levels, as part of an identity component [Crawford et al., 2014]. Instruction in a transnational era also demands more varied attention to the different nations and cultures and to the emotional processes that affect the different communities [Warriner, 2017; Zembylas, 2012]. Studies on dual identity in the transnational era cope with the implications of the identity regarding civil conception of immigrants, claiming that one should develop a new and complementary analysis that also relates to nationalism with regard to origin, place of birth and sense of attachment [Bloch, 2017; Erdal\&Sagmo, 2017].

\section{What's Missing?}

A review of the literature on policy towards immigrants in the educational system and on immigrant teachers shows that we lack attention to veteran immigrants and their encounter with immigrant students. The literature, as indicated, concerns the integration of immigrant teachers as part of the process of their assimilation into the host society and into their jobs and professions, as well as encounters between immigrant teachers and immigrant students, but not that of veteran residents who are no longer defined as immigrants by the establishment and school. In a society in which one third of the population consists of immigrants, there is a high probability that some teachers immigrated during their childhood. This study seeks to highlight the bond between the VITs migration stories in encounters with students and to claim that the teachers' personal experiences help shape their conceptions and their behavior with immigrant students.

\section{The Israeli Context: The Education System's Approach and the Integration of Immigrant Teachers}

The public educational system in Israel has undergone changes since the establishment of the state and thereafter, in parallel to the changes experienced by all Israeli society. During the early days of the state, the prevailing policy followed the melting pot metaphor and called for assimilation, as echoed by the educational system as well [Kimmerling, 1995]. Acceptance of immigrants in the educational system as of the late 1970s launched a new cultural era in which the idealism and patriotism that characterized the early days of establishing the state had since attenuated. In accordance with the changes affecting society, the educational system adopted an immigration policy accompanied by structural reforms, but these proved unsuccessful. During the 1980s, economic problems led Israel to follow global economic trends and enable broader adoption of the free market approach. The educational system, too, upheld more pluralistic conceptions: In 1980-2000, it underwent transition from uniformity to pluralism and its economic and social conceptions shifted towards liberalism and democracy, in the spirit of the capitalistic economic market. Freedom and individual rights took center stage as part of postmodern approaches and the post-colonialist spirit. In the educational system, schools and parental involvement therein were accorded greater recognition and room for autonomy [Israeli Ministry of Education, 2005]. 


\section{The Research Paradigm - The Narrative Paradigm}

Josselson and Lieblich define narrative research as "any study based on discourse or on people's verbal accounts of their experiences. Such a story need not compose a complete autobiography; it may be short descriptive statements or narratives, formed in the teller's personal language and style, in response to the researcher's open-ended question" [Josselson\&Lieblich, 2011: 326].

\section{Expressing and Establishing Identity}

The stories people tell about themselves enable us to learn about them and their conception of life. The story as a tool for understanding personal identity has become even more essential in an era in which the boundaries among populations, nations and other components of identity have become obscured.

\section{Narrative - Constituting and Creating the Teller's Identity}

The stories that people tell about themselves to themselves and others express the manner in which they choose to remember and describe their experiences. The story also serves certain purposes or possesses some specific function(s) itself [Alasuutari, 1997]. A story is summed up by its end point(EP) [Gergen\&Gergen, 1988] - the literary message, point or claim that the teller wants to transmit to listeners. To analyze the story in its many contexts, one should adopt a holistic approach that is a key part of narrative ontology. Holistic strategy includes five practical aspects referring to the EP - two that help identify it and three that attempt to understand why it was created as it was: The story as a whole unit and not as separate and isolated parts thereof; the content and form so expressed; the context (stories do not just fall from the sky) that is complex, essential and substantial; the analysis of life and the basic ontological assumption that they imitate one another and one does not exist without the other and finally the possibility of analysis through multidimensional and interdisciplinary lenses. We thus expand our vision within the framework of narrative analysis, with attention to the variety of dimensions and psychological, cultural and social influences that constitute a key challenge in narrative analysis [Spector-Mersel, 2011, 2014]. This paradigm suits the present study in which the interviewees, i.e., the teachers, presented their world views and activities with students through the story of their own immigration in the context of the migration processes they underwent. Narrative research describes an aggregate of features and life experiences wherein the identity of the interviewee is diachronic, historically deep and evolves over time, suiting research that examines "leaps" in life events: The teacher extracts memories of her own migration experiences to explain those of her students. Narrative research is tolerant of internal contradictions in human identity and in the story itself [Gergen\&Gergen, 1988].

\section{Method}

The teachers' stories were analyzed using Spector-Mersel's six selection mechanisms through which people tell their stories, claiming that the mechanism is not chosen randomly but is intended to serve the EP [Spector-Mersel, 2011]. Inclusion - what is told, which facts and experiences are mentioned and the connections among them, if any; sharpening - the themes, periods and events that the teller chooses to emphasize and underscore in the story; 
omission - failure to mention themes, periods or events perceived as irrelevant to the desired EP; silencing - failure to mention themes, periods or events perceived as contradicting or negating the EP; flattening - mentioning a topic superficially and minimizing its significance (saying something but also stating that it lacks importance) and "appropriate" meaning attribution - providing meaning to a certain period, event or fact of concern to the EP of the story, even without necessarily paying attention to its original significance.

\section{Data Collection}

Data collection was accomplished through narrative interviews, a method developed by German sociologist Fritz Schütze in which the interviewee seeks to talk about a certain experience. The Latin root narare means to report or tell a story. The chief principle of this idea is to enable the interviewee to present a spontaneous narrative/story without any intentional intervention on the part of the interviewer (unlike the question-and-answer interview schema) [Bruner, 1987; Flick, 1998]. The interviews took place at schools, each extending over a period of $1-1 \frac{1}{2}$ hours. Teachers were asked questions in two stages: During the first stage, a broad question was asked that invited them to speak freely about teaching immigrants: "Tell us about the experience of teaching immigrants." Once she has finished talking about this topic, additional questions are asked in the second stage to solicit attitudes to various parameters defined for this study, namely the teacher's attitudes towards language, relationships with parents, original and Israeli culture, military service and Jewish identity [Rosenthal, 1993]. The research proposal, that includes details of the procedure of referral to interviewees and of the questions, was approved by the ethics committee of the school at which the research took place.

\section{Population and Participants}

In-depth interviews were held with ten female teachers who were not born in Israel but moved there from countries that comprised the FSU. It should be indicated that we interviewed another five such teachers who came from Canada, Argentina and France and found similar patterns, but for the purposes of this study, we analyzed only interviews of teachers from the FSU, as most of the new immigrants at the schools involved indeed originated in FSU countries, according an outstanding advantage to teachers who speak their language. The teachers had come to Israel more than 20 years ago, some in their childhood and some in their adolescence. They studied and taught in regular classes throughout their careers but have been teaching immigrants for at least five years at four high schools in central Israel that have a sizable representation of immigrants (at least a quarter of the student body). We chose to interview teachers who have been teaching immigrants for at least five years because the study aspires to base itself on teachers familiar with teaching in general and teaching immigrants in particular who have had experiences in and long-term acquaintance with the field, so that the results do not consist only of the teachers' initial reactions to working with immigrants. Most were trained as teachers in Israel and have had many years of experience teaching subjects such as English and other humanities. Some are also homeroom teachers, including one who serves in the capacity of immigrant student coordinator. Assignment of VITs to immigrant classes was the result of differences in matriculation examinations for regular and immigrant students, allowing the latter to be examined in their native languages. Consequently, immigrant 
classes were set up with specific teachers asked to teach the special syllabus in the language of most Israeli students. The teachers assigned to these classes were not trained specifically for work with immigrant students and apparently began doing so because of their familiarity with the language (although not all immigrant students speak the same languages, most are indeed Russian-speaking). Besides teaching immigrants, they continue to teach their regular classes of native-born students.

\section{Findings}

The study's research question focuses on the meaning that teachers assign to the encounter with immigrant students, considering their own personal immigration experiences and based on Berry's model with regard to individual coping strategies applied when facing a new culture. Berry claims that there are two basic positions: Attraction to the culture of origin and consequent desire to preserve it (depending on the degree of significance that the immigrant ascribes to this culture) and attachment to the new culture (here as well, it depends on the degree of significance assigned to internalization of the culture as part of the immigration process)[Berry, 1992; 2003]. Narrative analysis of the findings, using story mechanism identification, revealed that the stories have two EPs, reflecting the different meanings that a given teacher accords to the encounter between her own immigration story and that of her students, combined with Berry's two conceptions of the integration process [Spector-Mersel, 2014]. This section of the study presents and explains the two EPs. The first expresses the buffer between cultures, conforming with the assimilation model reflected in the first part of the study's title, based on one teacher's remarks: "What I did was toburn bridges, not looking back or giving myself a moment to cry; whatever was - remains there," while the second conveys a declaration that one may maintain a combination of simultaneously present identities according to the integration model, also deriving its part of the title from a teacher's response: "I know it is possible to be both Ola (Russian name) and Ayala (Hebrew name)."

End Point 1: "What I did was to burn bridges, not looking back or giving myself a moment to cry; whatever was - remains there."

The central ideas expressed by the EPs originate in mechanism analysis:

Generalization.EP1 presents a look at "here" and "there" without connection to one another and even emphasizes detachment as an integration tool. The teachers who present such conceptions describe the vast difference between the two worlds, both their world as immigrants and the process of integration into Israeli society. At times, description of this disparity is overt (as in the explicit statement describing the EP: "What was there, remains there") and at times less unambiguous, although one may understand that the teacher is relating to these worlds as mutually exclusive. To be Israeli, one must cease being Russian: "In school, we spoke only Hebrew," to stress integration. The buffer they describe is not only between their original and Israeli cultures but also between the two periods of immigration, theirs and the students':

In our day it was different at school. Teachers did not speak Russian to us. Today, they hardly speak Hebrew at school...

Today's immigrants are running away from countries that are falling apart.

... Those who came from Moldova, Ukraine and Belarus came from places that today have no values. They allow students to copy from one another during examinations. The students had little to eat and did not identify or feel any affinity for their countries of birth. They were 
a lost generation there as well. They are survivalists. They are not familiar with the flag and national anthem of Ukraine, observe no holidays and do not need to exchange one identity for another because they have no previous identity. When they say, "I am Ukrainian," they don't know what it means. In our day it was different. We left a place that was a great power. We left our pride behind.

In other words, the teachers encourage integration into Israel, but emphasize that today's students are not "leaving anything behind" because they come from places that have no national characteristics or values.

Attention to what they had "there" and what we have "here" and the disparity between them is expressed through stories in which the teachers mention their own experience in describing the absorption of immigrants today - a kind of generalization stating that every culture (Israeli and Russian) has its own characteristics and one must choose. One abandons a previous life and adopts a new identity in its stead, as in the following example:

The counselor, my (tenth-grade) student and I had a meeting. The counselor asked the student how her parents welcome her when she comes home. "Do they hug you? Kiss you?" She said no. I translated the conversation and the counselor said to me: "In Russian culture, there are no hugs and kisses." And as I translate, I say: "I'm 34 years old. My mother has not hugged me since I was ten. I hug my children all the time. I kiss them and make up for everything I did not get. Children need warmth and love, and the parents do not provide it. I give my children and my students what I missed." At the end of the meeting, I hugged and kissed her [the girl]. Hugging and kissing is Israeli, and I want them to become Israelis, just as I did.

Sharpening. In this story mechanism, teachers sharpen difficulties in their migration stories and/or those of their students, thereby emphasizing the EP's reflection of the vast disparity between the two cultures, between native-born Israelis and immigrants, transition from a foreign and different identity to an Israeli one, with no interim situation between them. The following example sharpens the cultural disparities and the place of the teacher - who shifts between "there" and "here" as though between two different and distant worlds - and the new immigrant student, who comes from one culture and is assimilated into another:

When the immigrants came to my class, they would not leave it. They could not communicate and had no Israeli friends. For them, Israelis were strange and different. They were always withdrawn among themselves. Even at school, they did not participate, they did not become involved.

In the same interview, this teacher described those immigrants who did integrate successfully:

Among them are girls who are motivated to integrate. They learned Hebrew, left the classroom, got to know new friends and even when their friends spoke to them in Russian, they responded in Hebrew at times.

One aspect of sharpening is emphasizing other stories of the teacher and students, with the teacher explaining that her experiences differ from those of her students, thereby sharpening the vast disparity in experiences typical of the two respective periods of migration.

... Life there was difficult because at the end, there was no longer any ideology. We had to cope with numerous difficulties concerning language, studies and work. We were five Russians. When we came to school, we always broke up and did not speak Russian so that people would not say: "Look! Here come the Russians." This is not the case among my students. They remain with people originating in their own culture - and there are a lot of them. 
Omission. The teller omits sections of her story that she does not consider relevant to the main idea. Some of the teachers noted that they immigrated, but did not specify their experiences in a structured and extended manner. It was as if they wanted to convey the facts but not detail the experience itself. The teachers say that they immigrated and became Israelis but do not describe in detail how they preserved their original characteristics or speak about the process of leaving their previous identity behind. They emphasize their integration and socialization into the Israeli ethos. For example, one teacher speaks about the course of her life, providing few details about immigration and more about absorption in Israel:

I came here as a little girl and learned Hebrew at school rather quickly. The Ulpan (immigrant Hebrew course) did not really teach us Hebrew. I was a good student... After high school, I served in the army. I have a bachelor's and master's degree from the university... I tell my students: "If I can do it, so can you..."

Her description presents little about immigration but numerous details of her integration in Israel. Here, her omission expresses her desire not to talk about difficulties and not to introduce them into her immigration story. Her impulse to integrate, to stay strong and to perform activities that will contribute to social integration (military service, higher education) conforms to Berry's assimilation pattern.

Silencing and Flattening. This mechanism stood out in the teachers' stories, as they silence and/or flatten an entire period so that it does not "disturb" their integration in Israel. The gaps and schisms described by the teachers are not only between "there" and "here" but also between the story of their experiences and those of their students, that display some similarity yet also exhibit highly different characteristics, e.g.:

At our school, studies were different. We had order and discipline. We respected our teachers... We were used to different standards and other rules of politeness.

Appropriate Meaning Attribution. Such attribution concerns the meaning of a certain event or fact conforming to the EP. In this mechanism, I chose to relate to the physical and symbolic aspects that arose in interviews and transmitted the meaning of the EP in one sentence. The immigrants are different, the immigrant coordinator tells us: "No one wants to teach them. From the beginning of the year, their homeroom teacher was switched three times and five months have already passed since the term began." The issue of "them" as immigrants vs. "us" as Israelis arose in this pattern, as the image of the immigrants is not good ("they copy each other's exam answers," "they try to bribe us to get good marks," "they talk during class without raising their hands"). The teachers prefer not defining themselves by the same identity and also aspire to help the students undergo rapid transition to the Israeli ethos and bid farewell to negative generalizations applied to their culture of origin.

In summary, this pattern, with all its different manifestations, describes a schism between the identity of the Russian immigrant and that of the Israeli, identities that cannot coexist. It is a situation of a non-hybrid identity and of behavior according to Berry's assimilation pattern. In other words, I who "burned bridges" have already integrated as an immigrant and therefore I do not underscore or even limit or conceal my Russian origin in the story. He, the immigrant student, has not yet integrated and the teacher emphasizes his being an immigrant and a Russian and how different he is at the integration stages at school and in society, as she encourages him to undergo the process that she underwent as a strategy for optimal integration. Perhaps by describing the experiences of the immigrant student, the teachers will be able to review their own personal stories without telling them in the first person but 
rather by describing them and perhaps experiencing them in discussions about their students and the challenges they face: "I know it is possible to be both Ola and Ayala."

End Point 2: "I know it is possible to be both Ola (Russian name) and Ayala. (Hebrew name)"

Generalization. In such cases, teachers integrate their attitudes towards their previous and current identities and those of their students. The teacher actually recreates her experience and reacts to it as she faces immigrant students (e.g.: "It was good for them to speak Russian or all the Russian speakers kept among themselves, so I speak Russian with my students and allow them to stay together). This pattern yields integration between the identity of the immigrant as a Russian and an Israeliand effectively emphasizes the possibility of manifesting two identities simultaneously. The student and teacher are both perceived as Russian immigrants and Israelis, leading to acceptance of a hybrid identity: I can be a Russian immigrant, an Israeli and a student. This point of view integrates identities and considers migration and transition to be more flexible and bidirectional processes. The teacher uses her past personal experience and those of her students - during their absorption and at present as immigrants - and also experiences the present as a veteran immigrant who helps students and provides them with examples of feelings similar to those that they experienced as immigrants, emphasizing that they remain in a dual position, even after years of life in Israel.

The teachers describe their life experiences as a source of information, linking them with what students are now undergoing by applying generalization:

When I came to Israel, I received so much assistance from the state. We were at an Absorption Center... I met the most charming people. Thanks to them, I am in the position I'm in today... They took me in hand and put us in an Ulpan and school. I am still in contact with my teachers from that time... I received so much and I want to give something back. It is not easy with my students today. Many single-parent families are also immigrants still at the adolescent stage of life, itself a complex period. Through them, I experience what I went through and am attempting to do what was done for me.

Another example of generalization:

At schools, there are children who want to go out and work and I understand them. I know that they have to do it for food. I know. It is very, verydifficult. But you also need a high school matriculation diploma. I am trying to push them, to give them motivation. I try to show them the good, because it's hard for the immigrants to perceive while they are still undergoing difficult migration experiences. By contrast, I see them from the perspective of time and make life clearer for them.

Sharpening. In the following examples, the teachers sharpenand emphasize differences, underscoring their claim that they underwent a process similar to the one their students are now experiencing:

I describe a feeling about not being able to understand anything. When I first came to Israel, I went to Tel Aviv on Memorial Day. I heard the siren. Everyone stood still, but I had no idea what was happening. I returned to the kibbutz to which we were assigned and told my friends: "You won't believe what happened today in Tel Aviv. Someone took over people's brains for one minute." I purposely told it that way, so that they would understand that there were aspects of this society that I cannot comprehend to this very day. We don't know the names of the Prime Ministers and the popular singers that the Israelis know. Immigrants have to start building new stores of knowledge about everything, all at the same time. 
Another example that sharpensdifferences but also provides a solution to the disparities is that of a teacher whose daughter was inducted into the army. She describes her lack of experience and familiarity with this process:

I was not in the army. My daughter was inducted into the army. I have no idea what the army is like in Israel. When she came home, I said to her: "I don't even know what to ask you. Tell me what I have to ask."

I have a feeling that Israeli culture does not have anything different from what you had there. Today, all you have there, like Facebook or Instagram, you have here as well. The gaps are not so wide and crossing them is a lot less dramatic than it once was.

Another one talks about the social context through the Internet in the same spirit:

They are not leaving their friends, language and culture behind because they always have contact via the Internet.

Recreating the teacher's immigration experience attests to her ability to contain the story of a person who underwent migration and who helps others with an identical process to this day. In this case, her hybrid identity that reflects integration: One may be absorbed into society without giving up one's identity and former systems of contacts. I can be both and my students can now be both, thanks to more open conceptions and to technology that enables preservation of transatlantic contacts.

Omission. As the description of the main idea is a continuum from there to here and a process of continuity that is interpreted as positive and productive, in which the identities integrate, the teachers flatten experiences of difficulty or mention that they happened and are over and that "Israeliness" was the answer to all problems. At times, they even begin speaking about difficulties and then suddenly stop. For example, a teacher telling her story said: "To this day, when we sit down at the Pessah Seder, I cry because all my family is not here..." Then, she cries and asks to stop recording. She allows some room for feelings of pain and yearning, but does not elaborate on them and maintains a description harmonious with both identities. She does not want to "spoil" her story with parts about difficulty.

Silencing and Flattening. Together with attention conducive to coexistence, one teacher reports that she told her class about Hebraization of names, but only mentioned it briefly and superficially (flattening). She wanted to be able to say that she raised the issue among her students, but did not discuss it in its natural contexts of identity, melting pot and multiculturalism:

In the lesson we had about names, I told my students that in the 1950 s and even in the 1990s, they changed the immigrants' names, asking them what they thought about it. They said that it wouldn't bother them. One girl said she changed her name and had no problem with it.

The teacher apparently mentioned various contexts and views concerning names, pointing out a student who changed her name and revealing that she herself added a name to her original one. She did not judge or attempt to preach, thus effectively enabling choice and freedom to reinforce a dual identity - not as the result of coercion or anticipated placation but out of free choice according to what suits each immigrant.

Appropriate Meaning Attribution. In other situations, teachers describe the EP that emphasizes duality and even use their previous knowledge to help their immigrant students. That same teacher who spoke about names said the following in an interview about herself:

I did not change my name but added one. I can be both, both Ola and Ayala.

In other words, she does not give up her previous identity as manifested in the Russian name Ola but appended an Israeli name as well (Ayala), affirming that she can be both. 
Appropriate meaning attributionis also evident in the following examples of the EP's meaning:

a) Teacher writing to parents: "Parents appeal to me regarding issues unconnected with education - municipal taxes, rent, filling out forms and so on, so I help them."

b) Teacher possessing a helping and mediating function regarding a draft notice, even though it is not part of her job: "I went with them to the Draft Board. I helped them with the language. It was lucky I came because there were no interpreters that day. In some cases, I had to call parents to obtain particulars."

The teacher thus helps families with language problems and in dealing with bureaucracy. Such functions are not part of her job description, but she perceives them as part of her job as a mediator who knows both languages and is familiar with the system in Israel, using her abilities to help recent immigrants. Note that she is not the slightest bit embarrassed about speaking Russian in the presence of Hebrew speakers, claiming that doing so in no way renders her less Israeli in anyone's eyes.

The above pattern underscored hybridity because through their immigrant students, the teachers discovered that some of their teachers' college classmates who are former immigrants from the FSU also became teachers of immigrant classes. They began sitting together in the teachers' room and speaking Russian among themselves. In general, it should be indicated that as of 2000, activities and programs through which immigrants from the FSU seek to maintain their original identity, culture, language and instructional style while living in Israel as Israelis are becoming increasingly relevant. Furthermore, for more than three decades, Israel has maintained schools and formal programs at schools in which Russian has a clearly defined place, such as the ShevachMoffet School in Tel Aviv. This study does not address such schools, but only State schools at which there is a significant representation of immigrants (about 25\%) but not a majority, whose presence legitimizes demands for special treatment.

The findings are summed up in the following table:

\begin{tabular}{|c|c|c|c|}
\hline EndPoint & ActualSituation & $\begin{array}{c}\text { Assimilation or } \\
\text { Split Identity and } \\
\text { Integration }\end{array}$ & $\begin{array}{c}\text { Non-Hybrid / } \\
\text { Hybrid }\end{array}$ \\
\hline $\begin{array}{l}\text { Assimilation } \\
\text { or Split in } \\
\text { Identity: } \\
\text { "What I did } \\
\text { was burn my } \\
\text { bridges" }\end{array}$ & $\begin{array}{l}\text { A student's exaggeratedly } \\
\text { Russian identity and an } \\
\text { absorption experience that } \\
\text { entails its abandonment. } \\
\text { In isolated cases, it emerged } \\
\text { that the teachers described } \\
\text { themselves as one kind of } \\
\text { immigrant and the immigrants } \\
\text { of today as another (e.g.: "We } \\
\text { did not become entirely Israeli, } \\
\text { but also do not resemble } \\
\text { today's immigrants"). } \\
\text { Alternatively, some teachers } \\
\text { note the similarity between } \\
\text { them and even their shared } \\
\text { distance from Israeli society. }\end{array}$ & $\begin{array}{l}\text { Split identity } \\
\text { or discrepancy } \\
\text { between the } \\
\text { students' } \\
\text { and teachers' } \\
\text { descriptions and } \\
\text { a concomitant } \\
\text { split between } \\
\text { Russian and Israeli } \\
\text { identities. }\end{array}$ & $\begin{array}{l}\text { Non-Hybrid: } \\
\text { Melting pot - I } \\
\text { have integrated into } \\
\text { Israeli society and } \\
\text { as such I reject or } \\
\text { limit attention to my } \\
\text { Russian origin. } \\
\text { Immigrant students } \\
\text { have not yet } \\
\text { integrated and the } \\
\text { teacher emphasizes } \\
\text { their Russianness, the } \\
\text { difference between } \\
\text { them and her and } \\
\text { between them and } \\
\text { native-born Israelis. }\end{array}$ \\
\hline
\end{tabular}




\begin{tabular}{|c|c|c|c|}
\hline EndPoint & ActualSituation & $\begin{array}{l}\text { Assimilation or } \\
\text { Split Identity and } \\
\text { Integration }\end{array}$ & $\begin{array}{c}\text { Non-Hybrid / } \\
\text { Hybrid }\end{array}$ \\
\hline $\begin{array}{l}\text { Integration } \\
\text { in society } \\
\text { and identity: } \\
\text { "I know I } \\
\text { can be both." }\end{array}$ & $\begin{array}{l}\text { Was life good for me as } \\
\text { an immigrant or not? Yes. } \\
\text { That is why I will help my } \\
\text { students even with matters } \\
\text { not pertaining directly to } \\
\text { education (language, parents, } \\
\text { culture, bureaucracy) }\end{array}$ & $\begin{array}{l}\text { Integration } \\
\text { between Israeli } \\
\text { and Russian } \\
\text { identities does } \\
\text { not disturb me and } \\
\text { even conforms to } \\
\text { integration into } \\
\text { Israeli society. } \\
\text { I do things with my } \\
\text { students that would } \\
\text { have been good } \\
\text { for me. I do not do } \\
\text { anything that was } \\
\text { not good for me. } \\
\text { For example, my } \\
\text { students and I are } \\
\text { both Russian and } \\
\text { Israeli. }\end{array}$ & $\begin{array}{l}\text { Hybrid: I am both } \\
\text { Russian and Israeli } \\
\text { and so are they. } \\
\text { This pattern enables } \\
\text { combination among } \\
\text { identities. }\end{array}$ \\
\hline
\end{tabular}

Although the conclusions are presented in clearly separated and discrete table format, the teachers' views and activities were actually situated along continua. Categorization may facilitate comprehension of patterns, but the actual continua range from integration to schism and from hybridity to partial hybridity. Realities are by no means as dichotomous as the table would imply. Hence our research emphasizes the mobility and flexibility of the immigrants' stories. The findings showed that the teachers' conceptions are patterns of intercultural (hybrid) integration and of schisms between cultures and identities (non-hybridity) that affect their approach to their immigrant students.

\section{Conclusions}

In this study, teachers were asked about their encounter with immigrant students and instructed to speak freely according to the spirit and conception of the narrative approach. In response to the question concerning their experiences teaching immigrants, the teachers brought up stories of an autobiographical nature without even being asked to do so. While recounting the stories, the teachers formed connections between them and those told by their immigrant students, as well as the students' experiences and how they cope with them. Each story and its ancillary connections enabled examination of the development of their identities [Riessman \& Speedy, 2007]. The study found that teaching immigrants returned each VIT to her own immigrant experience as engraved in her memory. The manner in which the teacher recalled her immigration story and absorption experience became a point of departure from which she related to her immigrant students. The teacher's identity conception, migration process and the manner in which she constructed her memory is the context in which she acts in coping with her immigrant students. This is a holistic approach that enables examination 
of each teacher's story as a totality, considering the connection between her job as a teacher of immigrant students and her status as a veteran immigrant herself. The teachers' stories leaped back and forth between descriptions of students to the process of their own absorption, between the students' experiences to their own. The connections thus formed reflected the meaning that teachers ascribe to migration events that they experienced and the interpretations they accord to them, that accordingly affect their behavior with their students [Spector-Mersel, 2014].

Some of the findings showed that two patterns stood out regarding the meaning that teachers accorded to the encounter between the two stories of immigration, of which the more prominent was hybridity, in which the teachers described themselves and their students as immigrants and as Israelis. The global and transnational era, combined with the weakening of the melting pot and assimilation conceptions and the rise in support of multiculturalism, provide an opportunity to expand the identity of teachers and students alike [Dinnerstein et al., 1990; Pries, 1999]. With the decline of the Sabra culture and the Zionist ethos of the early days of the state and after the wave of immigrants from the FSU during the 1990s and the broader public presence of different cultures, especially Russian, some teachers may have allowed themselves greater revitalization of their culture of origin. Subsequently, their identities were reawakened as a result of the encounter with immigrant students.

In the literary discourse concerning hybridity, Bhabha noted the reciprocity of instruction between cultures and of identity formation [Bhabha, 1994]. The present study focuses on the split identity of teachers. Studies of immigrant teachers emphasized their instructional function, indicating that they perceived themselves as bridging between school culture and immigrant family culture [Virta, 2015]. According to the hybrid conception, recognition that I am an Israeli but also have another national-cultural identity enables a broader variety of attitudes towards immigrants besides that of the melting pot. Even if formally rejected, the melting pot conception still serves as a covert or temporary tool in establishment and general hegemonic culture to integrate groups of immigrants [Sever, 2004, 2004]. A narrative analysis of interviews with teachers and an attempt to cope with the question of the teachers' identity led to the conclusion that there are two chief methods of expressing identities in stories assimilation of Israeli values instead of maintaining one's previous identity and integration between identities.

Another conclusion concerns the changing conceptions in the educational system and increased receptivity to multiculturalism and multilingualism in school space. Theavailability and affordability of foreign travel in the global and transnational era may also lead immigrant families and the teachers themselves to visit their countries of origin, thereby preserving and maintaining contact even after moving to Israel [Vertovec, 2004]. A complex cultural, linguistic and sometimes also religious identity is legitimate, with its own place in society, often evoking an open-minded and positive attitude among the public [Levitt et al., 2003].

\section{Implications and Practical Conclusions: Immigrant Teachers as Bridge Builders}

This study proposes that immigrant teachers undergo examination of their transition between identities during immigration and of the effects of their experiences on their educational conceptions. Once immigrant teachers are aware of the patterns that typify them, we will be able to use them as bridge builders towards absorption of immigrant students - not 
(only) as an informal contribution and helpful act within the school itself, but as a key tool in terms of culture, society, pedagogy and education, forming ties between student and teacher, between teacher and family and between family and school community. So far, policies and schools have paid no attention to the unique contribution these teachers represent because of their personal experiences. The literature recognizes the importance of analyzing the teacher's identity in social, cultural, historical and political contexts only within the framework of their job as teachers [Rodgers \& Scott, 2008]. Attention to the experience and conception of immigration among immigrant teachers is required as part of their work with immigrant students. As teachers, their personal conception of immigration is not only an individual experience but one that accompanies new immigrants into Israeli society, confronting them in an intensive initial encounter. Consequently, they should become part of an educational system resource through recognition of their experiences, enabling them to assist with planning, preparation and creative thinking regarding the absorption of immigrant students.

\section{References}

Alasuutari, Pertti. The discursive construction of personality. Lieblich, Amia and Ruthellen Josselson (Eds.). The narrative study of lives, vol. 5. Sage, Thousand Oaks, CA, 1997: $1-20$.

Beijaard, Douwe, Nico Verloop, and Jan D. Vermunt. Reconsidering research on teacher's professional identity: An exploratory study from a personal knowledge perspective. Teaching and Teacher Education, Vol. 16, 2000: 749-764.

Berry, John W. Acculturation and adaptation in a new society. International Migration Review, Vol. 30, No. 1, 1992: 69-85.

Berry, John W. Conceptual approaches to acculturation. Chun, Kevin M., Pamela Balls Organista, and GerrdoMarín (Eds.). Acculturation: Advances in theory, measurement, and applied research. American Psychological Association, Washington DC, 2003: $17-$ 37.

Bhabha, Homi K. The location of culture. Routledge, London, 1994.

Bloch, Alice. Transnationalism and the state: Recurring themes and new directions. Ethnic and Racial Studies, Vol. 40 No. 9, 2017: 1508-1519. https://doi.org/10.1080/01419870.20 17.1300294

Bruner, Jerome. Life as narrative. Social Research, Vol.54, 1987: 11-32.

Crawford, Tony, Martha Lengeling, Irasema Mora Pablo, and Rocio Heredia Ocampo. Hybrid identity in academic writing: 'Are there two of me?' Issues in Teachers' Professional Development, Vol. 16 No. 2, 2014: 87-100. https://doi.org/10.15446/profile. v16n2.40192

Dinnerstein, Leonard, Roger L. Nichols, and David M. Reimers. Natives and Strangers:Blacks, Indians and Immigrants in America. Oxford University Press, New York, 1990.

Erdal, Marta Bivand, and ToveHeggliSagmo. Descent, birthplace and residence: Aligning principles of citizenship with realities of migrant transnationalism. Norwegian Journal of Geography, Vol. 71 No. 4, 2017: 208-221. https://doi.org/ 10.1080/00291951.2017.1369456

Faist, Thomas. The volume and dynamics of international migration and transnational social spaces. Oxford University Press, Oxford England, 2000.

Flick, Uwe. An introduction to qualitative research. Sage, London England, 1998. 
Gergen, Kenneth J., and Mary M. Gergen. Narrative and the self as relationship. Advances in Experimental Social Psychology, Vol. 21, 1988: 17-56. https://doi.org/10.1016/S00652601(08)60223-3

Gold, Steven J. The Israeli diaspora. Routledge, London and New York, 2002.

Hall, Stuart. New ethnicities. Donald, James and Ali Rattansi (Eds.). Race, culture and difference. Sage, London, 1992: 252-259.

Israeli Ministry of Education. Doch Dovrat: Hatochnithaleumitl'chinuch [Dovrat report on the national plan for education], 2005. https:/www.makorrishon.co.il/nrg/images/ stuff/news/Dovrat_05.01.05.pdf

Josselson, Ruthellen and Amia Lieblich. Narrative research and humanism. Schneider, Kirk J., James F.T. Bugenthal, and J. Fraser Pierson (Eds.). The handbook of humanistic psychology: Theory, research and practice. Sage, Thousand Oaks CA, 2001: 275-289.

Kimmerling, Baruch. Hayisraelimhachadashim: Ribuitarbuyotl'lorav-tarbutiyut [New Israelis: Multiple cultures without multiculturalism]. Alpayim, Vol. 16, 1998: 264-308.

Levitt, Peggy, Josh DeWind, and Steven Vetrovec. International perspectives on transnational migration: An introduction. International Migration Review, Vol. 37 No. 3, 2003: 565575.

Levitt, Peggy and Nina Glick Schiller. Conceptualizing Simultaneity: A Transnational Social Field Perspective on Society. International Migration Review, Vol. 38 No. 3, 2004: 1002-1039.

Pries, Ludger. New migration in transnational spaces. Pries, Ludger (Ed.). Migration and Transnational Social Spaces. Ashgate, Burlington VT, 1999: 1-35.

Riessman, Catherine Kohler, and Jane Speedy. Narrative inquiry in the psychotherapy professions: A critical review. Clandinin, D. Jean (Ed.). Handbook of narrative inquiry: Mapping a methodology. Sage, Thousand Oaks CA, 2007: 426-456.

Rodgers, Carol R., and Katherine H. Scott. The development of the personal self and professional identity in learning to teach. Cochran-Smith, Marilyn, Sharon FeimanNemser, D. John McIntyre and Kelly E. Demers (Eds.). Handbook of research on teacher education. Routledge, New York, 2008: 732-746.

Rosenthal, Gabriele. Reconstruction of life stories: Principles of selection in generating stories for narrative biographical interviews. Josselson, Ruthellen and Amia Lieblich (Eds.). The narrative study of lives (Vol. 1). Sage, Thousand Oaks CA, 1993: 59-91.

Sever, Rita. M'simahcholefet o matzavkiyumi? Alternatival'mediniutklitah [Passing assignment or existential situation? An alternative to immigrant-absorbing policies]. HedHaulpanHehadash, Vol. 87, 2004: 18-41.

Shenhav, Yehouda. The Arab Jews - A postcolonial reading of nationalism, religion, and ethnicity. Stanford University Press, Stanford CA, 2006.

Spector-Mersel, Gabriela. Mechanisms of selection in claiming narrative identities: A model for interpreting narratives. Qualitative Inquiry, Vol. 17, 2011: 172-185. https:/doi. org/10.1177/1077800410393885

Spector-Mersel, Gabriela. I was... until... since then...: Exploring the mechanisms of selection in a tragic narrative. Narrative Works: Issues, Investigations, and Interventions, Vol. 4 No. 1, 2014: 19-30.

Vertovec, Steven. Migrant transnationalism and models of transformation. International Migration Review, Vol. 38 No. 3, 2004: 970-1001. https://doi. org/10.1111/j.1747-7379.2004.tb00226.x 
Virta, Arja. In the middle of a pedagogical triangle - Native-language support teachers constructing their identity in a new context. Teaching and Teacher Education, Vol. 46, February 2015: 84-93. https://doi.org/10.1016/j.tate.2014.11.003

Wald, Kenneth D. Homeland interests, hostland politics: Politicized ethnic identity among Middle Eastern heritage groups in the United States. International Migration Review, Vol. 42 No. 2, 2008: 273-301. https://doi.org/10.1111/j.1747-7379.2008.00125.x

Waldinger, Roger. The cross-border connection: Immigrants, emigrants, and their homelands. Harvard University Press, Cambridge MA, 2017.

Warriner, Doris. Theorizing the spatial dimensions and pedagogical implications of transnationalism. Curriculum Inquiry, Vol. 47 No. 1, 2017: 50-61. https://doi.org/10. 1080/03626784.2016.1254501

Young, Robert J.C.Colonial desire: Hybridity in theory, culture and race. Putnam, New York, 1995.

Zembylas, Michalinos. Transnationalism, migration and emotions: Implications for education. Globalization, SocietiesandEducation, Vol. 10 No. 2, 2012: 163-179. https://doi.org/10.1080/14767724.2012.647403 